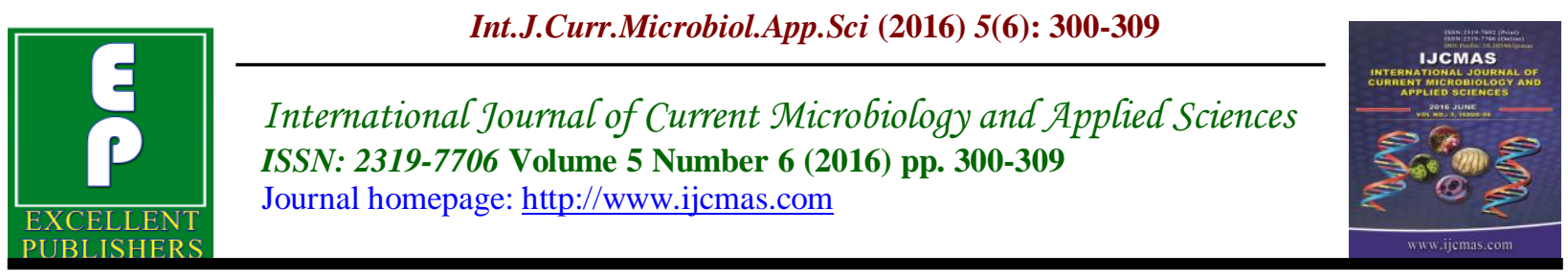

Original Research Article

http://dx.doi.org/10.20546/ijcmas.2016.506.034

\title{
A Comparative Study between Three Aquatic Plants to Phytoremediation of Lead from Wastewater
}

\author{
Nashmeel Ali Hassan ${ }^{*}$, Abdul-Rahman A. Al-Kubaisi ${ }^{2}$ \\ and Abdul- Hameed M. Al- Obiadi ${ }^{2}$ \\ ${ }^{1}$ Biology Dept. College of Science for Women, University of Baghdad, Iraq \\ ${ }^{2}$ Environmental research Centre, University of Technology, Iraq \\ *Corresponding author
}

\begin{abstract}
A B S T R A C T
Keywords

Wastewater,

lead, aquatic

plants,

phytoremediation.

\section{Article Info}

Accepted:

15 May 2016

Available Online:

10 June 2016

This study was conducted in vitro to identify the three plants the ability of a Ceratophyllum demersum and Hydrilla verticellata and Echhornia crassipes to remove the lead element of the sewage using different dilutions $(25,50,100) \%$ of wastewater for a period of thirty days each plant separately and compare the results showed that the three plants have the ability to remove lead from sewage and accumulation in their tissues was C.demersum removes bullets in the leg above the securities while H.verticellata plant accumulates lead in the root <paper <leg while leaf E.crassipes was has the ability to accumulate lead in the root <paper, as compared to the three plants in its ability to remove lead in the E.crassipes interweave appeared leaf ultra removal of lead capacity. The concentration of elements in the tissues in large quantities. And it found significant differences between the parts of the plant at the level of the probability $\mathrm{P} \leq 0.05$ in most of concentrations studied during the duration of the experiment, recorded significant differences among the three plants.
\end{abstract}

\section{Introduction}

Multiple wastewater Sources, there is domestic sewage, industrial waste and divert river water and as a result of increased industrial and agricultural development and increasing human activities led to an increase wastewater which requires wastewater treatment to achieve environmental sustainability.

The wastewater, one of the sources of environmental pollution in general and contamination of water resources is particularly so when put into rivers, seas and lakes without treatment and consequences of this it causes to all the health, agricultural and tourist areas which requires wastewater treatment before putting numerous methods of wastewater treatment but most are expensive and far for optimal performance to them. But the use of phytoremediation is the best method because it is inexpensive and environmentally friendly (Memon et al., 2001) and the means to use some of the plants that have the ability to reduce the level of contamination by certain mechanisms carried out by the plant lead to 
the removal or analysis of different contaminants (Sasaki et al., 2003). And that the processing plant is one of the vital technologies for green plants that are used to treat contaminants in the environment expel extracellular toxicity or reduce movement in the soil or water and at increasing the level of heavy metals within the plant tissue, the plant but that is compiled in special locations in the root or leg or converts to other forms non-toxic as possible be distributed and used again in the metabolic processes (Maine, et al., 1999).

Many plants can accumulate contaminants in their tissues and rid the environment of different minerals, some of which are essential for plant growth as key elements in the growth such as iron, manganese, zinc, copper, magnesium, nickel and others accumulates in the plant body, but an element is essential such as cadmium, lead, mercury and carbon source (Qian et al., 1999).

The accumulation of mechanical elements within the plant body is the fact that these toxic elements linked to the walls of the cells in roots or leaves which prevents they move through the wringer plant. or expel by mechanical especially to the non-sensitive sites in the cell as it is stored in the gaps (Hettiarachchi et al., 2012).

\section{Phytoremediation}

The term of phytoremediation comes from a Greek prefix "Phyto" and attached to latin word "remediation" to correct. Simply, it refers to utilize green plants to remove contaminants from soil and water (Mitra, 2012). It is cost effective, as ethically accepted, and it is less disturbed to the environment. The plants used in this ecofriendly technology must have a considerable capacity of metal uptake. There are many ways by which plants remediate contaminated sites.

\section{Phytoextraction}

Phytoextraction is the uptake of contaminants by roots and trans-located into aerial parts, which enrich with metals. To reach the acceptable level of metals, plants should use continuously. However, phytoextraction is among the best approach to remove contaminants from soil, sludge and sediment, it takes a long time (Malik and Biswas, 2012).

\section{Rhizofiltration}

Rhizofiltration is the uptake and concentrate (absorb and adsorb) contaminants by roots from pollutedarouses sources. The tolerance and translocation of the metals to aerial parts are irrelevant (Jadia and Fulekar, 2009).

\section{Phytovolatilization}

In phyotvolatilization, plants use to uptake contaminants from, soil, sediments and sledges transforming them into volatilized compounds after that, transpiring them into the atmosphere (Prasad, 1998).

\section{Phytostabilization}

It is defined as the use of transcription and root growth to reduce the mobility bioavailability of pollutants in the environment through creating an aerobic condition in the root zone and could be achieved via the addition of organic matter and soil (Hussner and Losch, 2005).

Heavy metals removed by the plants due to storage in the roots, stems, or leaves. The metals convert into less harmful substances within the plant or gaseous form and are released into the air through transpiration activities (Alluri et al., 2007). 


\section{Materials and Methods}

\section{Collection of plants}

Three types of aquatic plants collected represented b $(C$. demersum, $H$. verticellata. and E. crassipes) and samples of water from the Tigris River in the Jadiriyah district of Baghdad province (Figure1).

Figure.1 Show precipitation basins Elementary in Rustumiya station in Baghdad

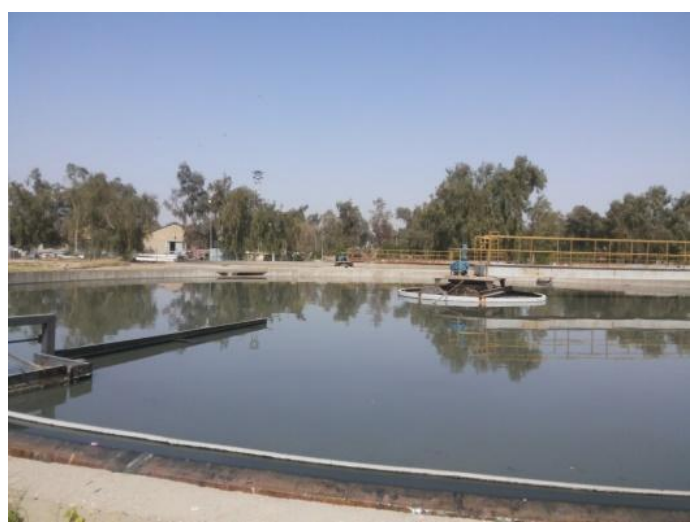

After three plants collected in plastic bags with a little water from the same site and transported to the laboratory as it was washed with fresh tap water and a small brush to remove sediment, aquatic invertebrates while preserving the root Alsairt.

Almost similar-sized plants planted in the age and stage in bathtubs glass of Education with the dimensions of $20 \times 30 \times 40 \mathrm{~cm}$, taking into account the volume of water found in ponds and then compensate the lost water, plants and distributed on four basins in order to avoid crowding and competition for the place.

And it has acclimatization of plants for the temperature of the laboratory $24^{\circ} \mathrm{C}$ was placed 10 liters of free chlorine water (up to 24 hours with exposure to the sun) in ponds until the test after it measured the proportion of lead element in the roots and leaves of plants and a sample of water of the river also will be remembered later.

\section{Collection of Wastewater}

Wastewater samples collected in the health of the liquidation Rustumiya station's picture (1) located in the Rustumiya region in the province of Baghdad, was the sampling of primary sedimentation tanks periodically quarterly and then added to chloroform to prevent any biological activity then transferred the samples by plastic containers clean to the lab where It was placed in the refrigerator degree 16:00 until a required analysis by the policies included in the (standereds 1995, Methods).

\section{Preparation Wastewater Dilutions}

Proper dilutions needed for wastewater with three replicates for each dilution, which was $(25 \%-50 \%-100 \%)$ of sewage water have been added to the tubs with dimensions of $20 * 20 * 30 \mathrm{~cm}$ experience which nine 4liter, and put the plants in the basin after the measure concentrations of heavy metals in the leaves and roots and then make the necessary measurement determined by atomic spectrometer Flame steps Flame atomic Absorption Spectrophotometer type (VGP 210 Buck, England) depending on (Senila et al., 2011)

\section{Heavy Metals Measurement}

After making dilutions necessary element lead with three replicates for each concentration were added to the tubs experience with the dimensions of $20 * 20 *$ $30 \mathrm{~cm}$ containing 4 liters of distilled water, taking into account the development of needed nutrients, as it put the plants in the basin after the measurement of the concentration of heavy elements in the 
leaves and roots and then make the necessary steps to measure determined by atomic spectrometer Flame Flame atomic Absorption Spectrophotometer type (VGP 210 Buck, England) depending on (Senila etal., 2011), as follows: Measurment of heavy elements in the leaves, stems and roots.

Collect 10 grams of leaves, stems and roots placed in a bottle an hour in an electric oven $105^{\circ}$ degree $m$ until the drought separately.

Weigh $1 \mathrm{~g}$ of dry specimen of both the leaves and roots in flasks glass Beakers and added a $12 \mathrm{ml}$ of nitric acid Center HNO3 (64\%) to conduct the process of digestion (Digestion) and then add $4 \mathrm{ml}$ of hydrogen peroxide $\mathrm{H} 2 \mathrm{O} 2$ (30\%). Preheat the specimen in the oven Oven MEMMERT ISO 9001, GERMANY)) at a temperature of $120^{\circ} \mathrm{C}$ for a period of 2 hours.

Lift the specimen from the oven and let cool for 24 hours and added a $10 \mathrm{ml}$ of distilled water. Nominated mediated by the nomination of the type Millipore paper (Whatman $0.45 \mu \mathrm{m}$ ) and the resulting solution placed in a glass cylinder (Salender) $50 \mathrm{ml}$ size and he finished with distilled water to the mark. Reference Blank attended the solutions in the same way without the use of a specimen.

It been estimated concentrations of elements in the models mediated by a flame atomic absorption spectrum Flame Atomic Absorption Spectrometry Model (VGP 210 Buck, England) English-made.

\section{Measurement of Heavy Metals in the Water}

Measure the amount of $150 \mathrm{ml}$ of water in ponds and well posts On was nominated in the volumetric flask $500 \mathrm{~mL}$. Added per 100 $\mathrm{ml}$ of the specimen $2 \mathrm{ml}$ of nitric acid HNO3. Attended lotions reference Blanks same way.

The estimation elements determined by atomic spectrometer Flame mentioned above (Dumitrescn \& Arpad, 2013).

\section{Results and Discussion}

Comparison of the three plants growing in the basins of wastewater in their ability to accumulation of lead Shapes (2, 3,4,5 and 6) can be observed comparing the results between the three aquatic plants (E.crassipes, H.verticellata, C.demersum) developing in the basins of wastewater in their ability to accumulation of lead in tissues showed plant E.crassipes has the ability to accumulation of lead to interweave more than vegetarian H.verticellata, C.demersum as accumulated leaf water hycianth $(0.453,0.749,0.885) \quad \mathrm{ppm}$ concentrations $(100,50,25) \%$ of the wastewater in the age of thirty-day experiment as shown in the table (18).

While for the plant H.verticellata wilted and died at the concentration of $50 \%$ of the wastewater in the fifth day of life experience, and it was the highest accumulation of his first day at the focus $100 \%$ of the wastewater $0.448 \mathrm{ppm}$, either for the plant C.demersum has died at a concentration of $100 \%$ the tenth day of life experience and reached the highest accumulation of him when the concentration of $50 \%$ in the tenth day of life experience. And reach through these results to be the order of the plants in the ability to remove lead from wastewater is E.crassipes $<$ C.demersum $<$ H.verticellata. 
Table.1 Compared to the concentrations of lead in plants E.crassipes, H.verticellata, C.demersum after different treatment concentrations

Of wastewater is expressed in units of ppm by different times

\begin{tabular}{|c|c|c|c|c|c|}
\hline \multirow{2}{*}{ LSD } & \multicolumn{3}{|c|}{ Concentrations - ppm } & Plants & \multirow{2}{*}{$\begin{array}{c}\text { Time of } \\
\text { Experemental }\end{array}$} \\
\hline & $100 \%$ & $50 \%$ & $25 \%$ & & \\
\hline $0.145 *$ & 0.362 & 0.177 & 0.0651 & Ceratophyllum demersum & \multirow{4}{*}{ First day } \\
\hline $0.209 *$ & 0.448 & 0.196 & 0.088 & Hydrilla verticellata & \\
\hline $0.182 *$ & 0.498 & 0.244 & 0.097 & Echhornia crassipes & \\
\hline- & 0.206 NS & 0.167 NS & 0.044 NS & LSD & \\
\hline 0.183 NS & - & 0.339 & 0.165 & Ceratophyllum demersum & \multirow{4}{*}{ Fifth day } \\
\hline $0.264 *$ & - & 0.745 & 0.204 & Hydrilla verticellata & \\
\hline $0.372 *$ & 0.832 & 0.445 & 0.201 & Echhornia crassipes & \\
\hline- & - & $0.215 *$ & $0.133 \mathrm{NS}$ & LSD & \\
\hline $0.204 *$ & - & 0.544 & 0.239 & Ceratophyllum demersum & \multirow{4}{*}{ Tenth day } \\
\hline- & - & - & 0.343 & Hydrilla verticellata & \\
\hline $0.467 *$ & 1.122 & 0.605 & 0.317 & Echhornia crassipes & \\
\hline- & - & $0.228 \mathrm{NS}$ & $0.172 \mathrm{NS}$ & LSD & \\
\hline- & - & - & - & Ceratophyllum demersum & \multirow{4}{*}{ Fifteenth day } \\
\hline- & - & - & - & Hydrilla verticellata & \\
\hline $0.351 *$ & 0.367 & 0.802 & 0.397 & Echhornia crassipes & \\
\hline - & - & - & - & LSD & \\
\hline- & - & - & - & Ceratophyllum demersum & \multirow{4}{*}{ Thirteeth day } \\
\hline - & - & - & - & Hydrilla verticellata & \\
\hline $0.285 *$ & 0.749 & 0.885 & 0.453 & Echhornia crassipes & \\
\hline - & - & - & - & LSD & \\
\hline \multicolumn{4}{|c|}{ NS:Not significant } & $* \mathbf{P}<\mathbf{0 . 0 5}$ & \\
\hline
\end{tabular}


Fig.2 Map of Baghdad described the site to collect samples

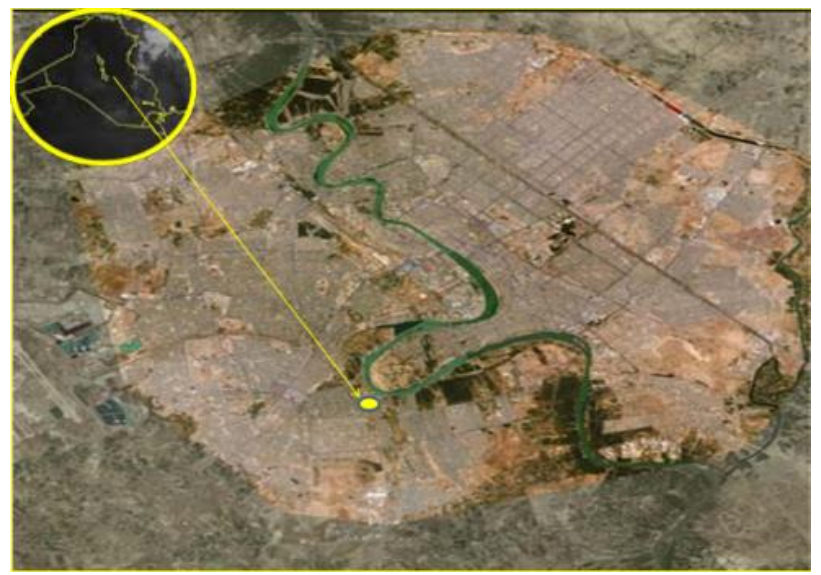

Fig.2 Compared to the concentrations (ppm) of lead in plants E.crassipes, H.verticellata, C.demersum after One day of experiment period.

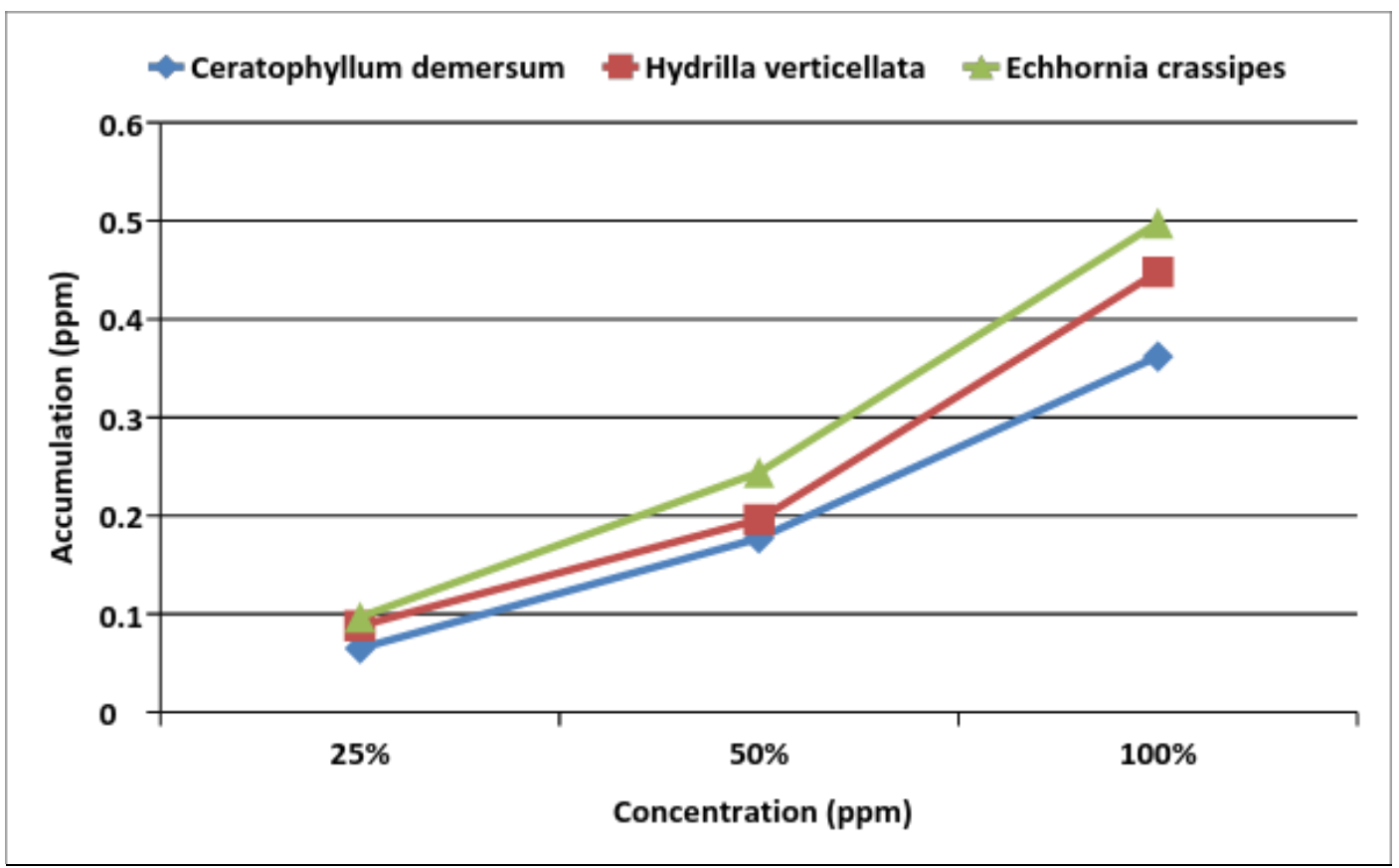


Fig.3 Compared to the concentrations (ppm) of lead in plants E.crassipes, H.verticellata, C.demersum after Five days of experiment period

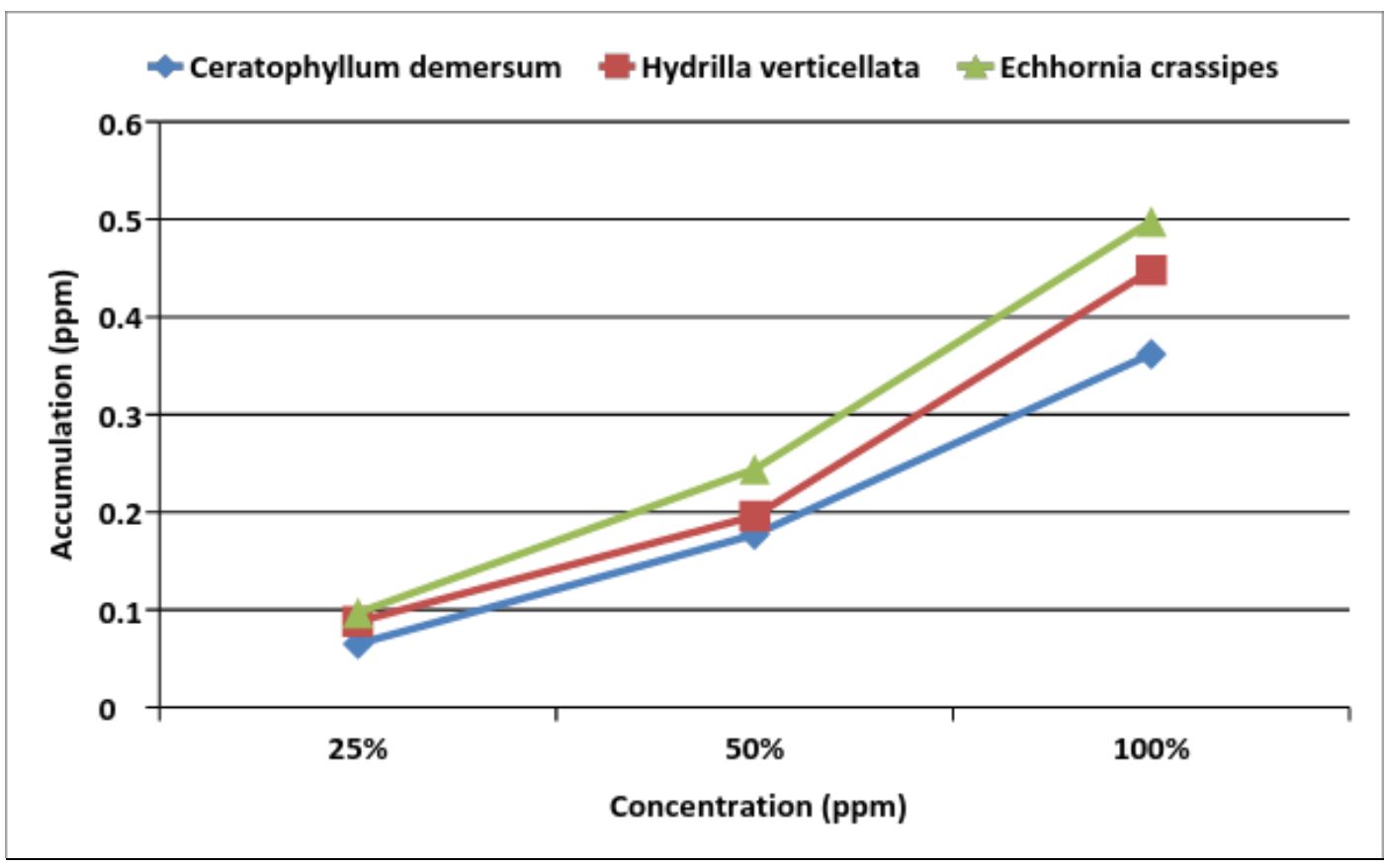

Fig.4 Compared to the concentrations (ppm) of lead in plants E.crassipes, H.verticellata, C.demersum after Ten days of experiment period.

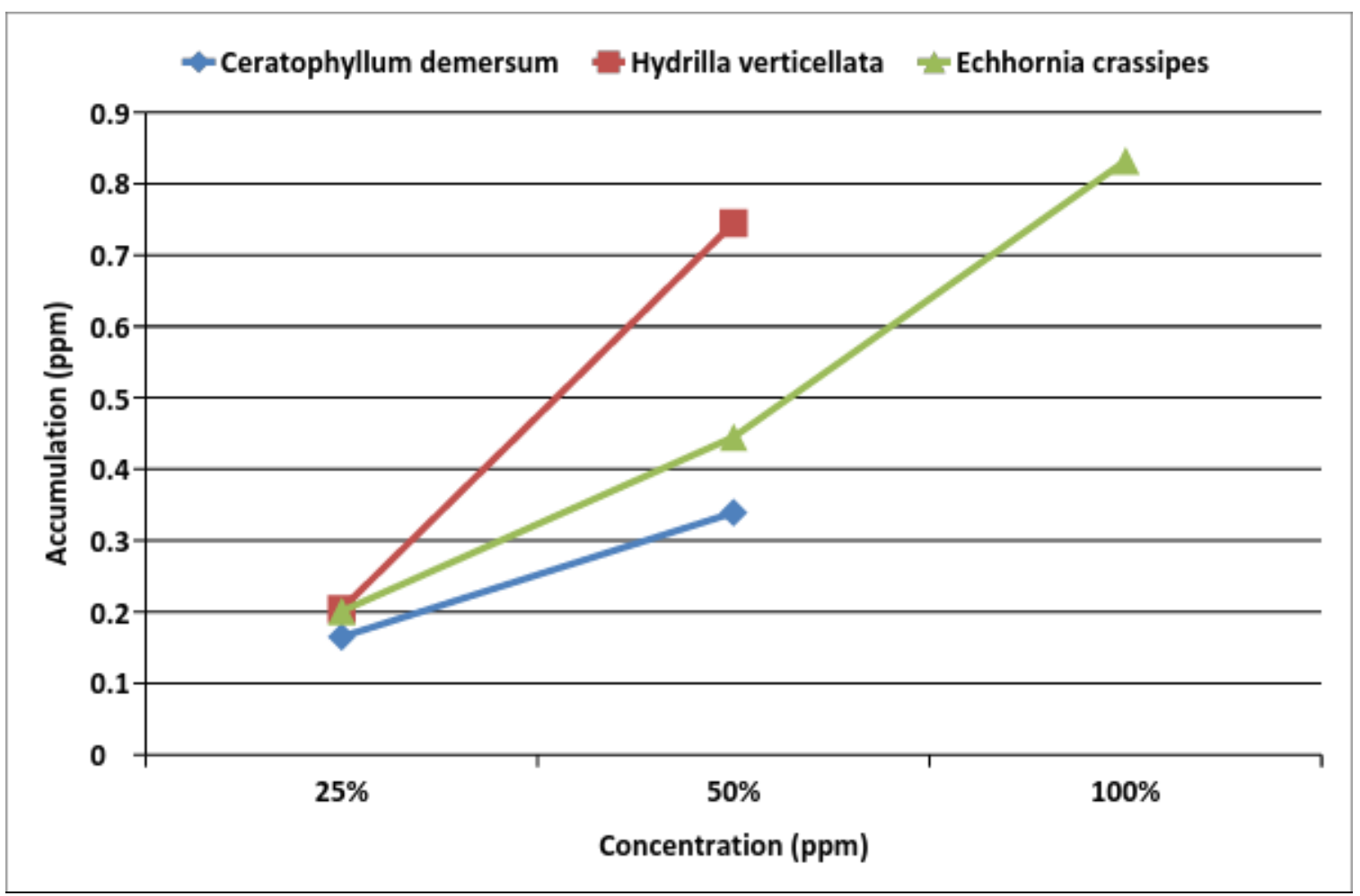


Fig.5 Compared to the concentrations (ppm) of lead in plants E.crassipes, H.verticellata, C.demersum after fifteen days of experiment period

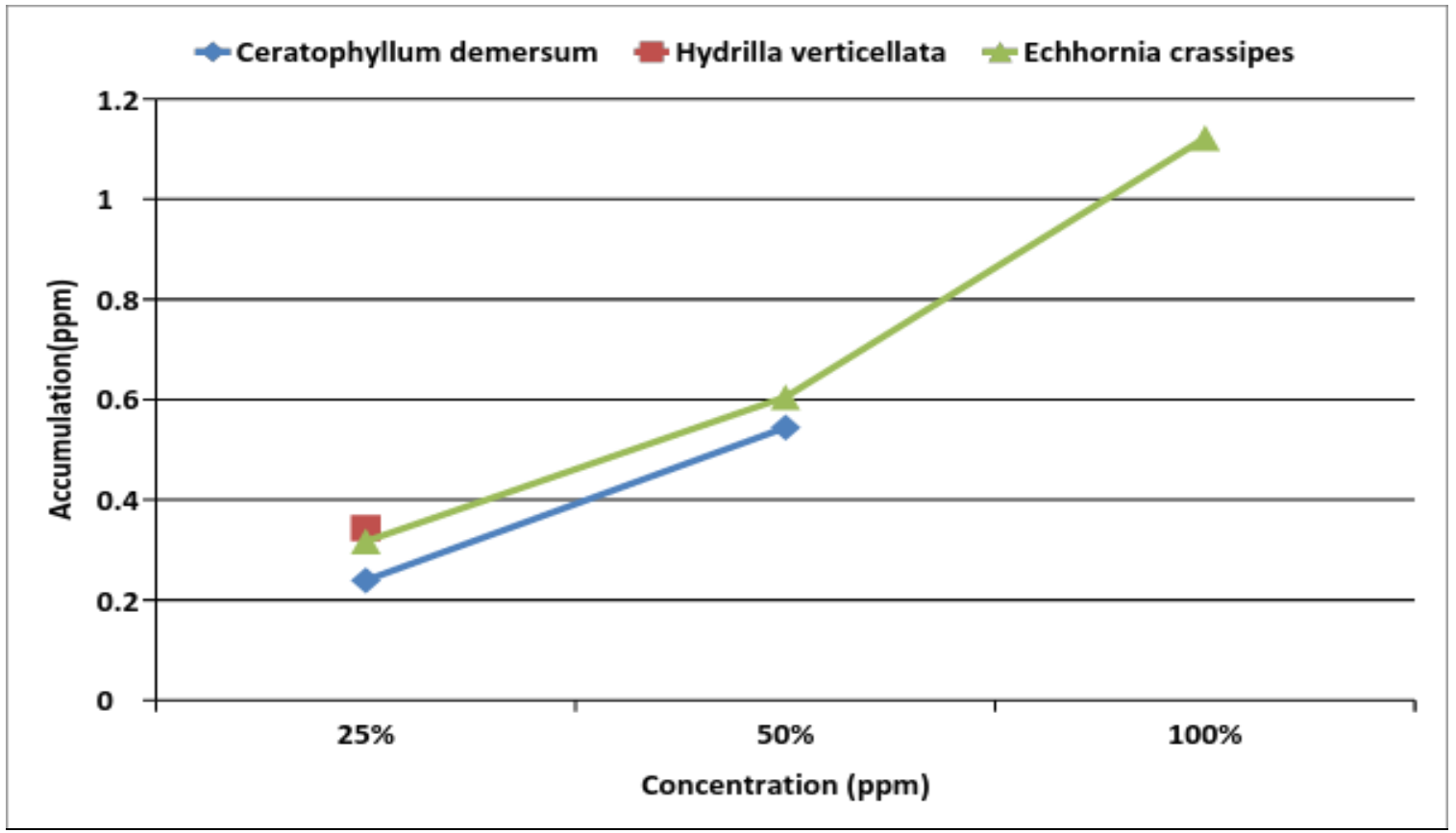

Fig.6 Compared to the concentrations (ppm) of lead in plants E.crassipes, H.verticellata, C.demersum after thirty days of the experiment of experiment period

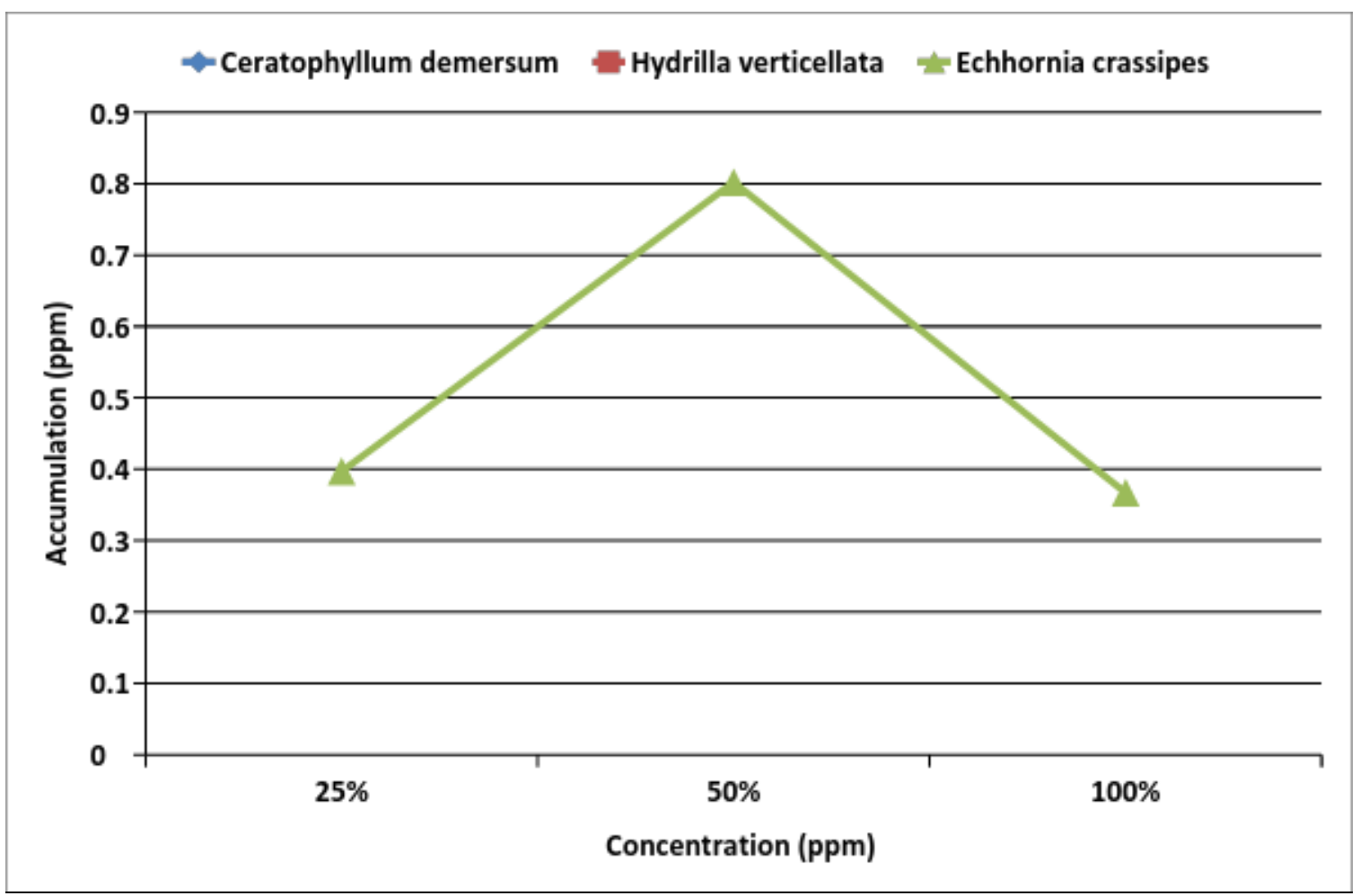


Results of statistical analysis showed that there were significant differences at concentrations $(25.50 \%)$ in the fifth and tenth days of life experience and the results showed no significant differences at all three concentrations in the first and fifth of lifetime experience. Consistent results of this study with (Soltan and Rashed, 2003) that the plant E.crassipes removes effectively clear amounts of metals $\mathrm{Pb}$ and $\mathrm{Ni}$ and $\mathrm{Mn}$ and $\mathrm{Cu}$ and $\mathrm{Cr}$ and $\mathrm{Co}$ and $\mathrm{Cd}$ and $\mathrm{Zn}$ of fresh water, especially in the concentrations of low-lying and that the economic success of Operation phytoremediation depends largely on the effectiveness of photosynthesis and the photosynthetic rate of growth rate of the plant.

Due to the fact E.crassipes high growth speed and productivity, which made them effective in the treatment of types of contaminated water (Xia and Ma, 2006). Found that E.crassipes capable of good growth in the waste water of dairy factories as it reaches the value of the chemical oxygen demand of more than $1160 \mathrm{ppm}$.

\section{References}

Alluri, H.K., Ronda, S.R., Sett allure, V.S., Bondili, J.S., Suryanarayana, V., Venkateshwar, P. 2007. Bio sorption: An eco-friendly alternative for heavy metal removal. African $J$. of Biotechnol., 6(25): 2924-2931.

Divya Singh, Archana Tiwari, Richa Gupta. 2012. Phytoremediation of lead from wastewater using aquatic plants. $J$. Agri. Technol., Vol. 8(1): 1-11.

Dumitrescn, L.S., Arpad, N.B. 2013. New Bioremediation Techniques of Heavy Metals From Aqueous Solutions Using and Phytoextraction Methods. Cluj Napoca.

Hettiarachchi, G.M., Arbelaez, S.C.A.,
Nelson, N.O., Mulisa, Y.A. 2012. Phytoremediation, Protecting the Environment With Plants, Kansas State University, United State Department of Agriculture.

Hussner, A., Losch, R. 2005. Alien aquatic plants in a thermally abnormal river and their assembly to neophyte dominated macrophyte stands (River Erft, Northrhine - Westphalia). Limnologica, 35: 18-30.

Jadia, C.D., Fulekar, M.H. 2009. Phytoremediation of heavy metals: Recent techniques. African $J$. Biotechnol., 8(6).

Maine, M.A., Sune, N.L., Panigatti, M.C., Pizarro, M.J. 1999. "Relationships between water chemistry and macrophyte chemistry in lotic and lentic environment." Arch. Hydrobiol., 145(2), pp 129-145.

Malik, N., Biswas, A.K. 2012. Role of higher plants in remediation of metals contaminated sites. Scientific Reviews and Chemical Communications, 2(2): 141-147.

Memon, A.R., Aktoprakligil, D., Ozdemir, A., Vertii, A. 2001. Heavy metal accumulation and detoxification mechanisms in plants. Turk. J. Bot., 25: 111-121.

Mitra, N., Rezvan, Z., Seyed Ahmad, M., Gharaie, M., Hosein, M. 2012. Int. J. Ecosystem, No. 2: 32.

Mudgal, V., Madaan, N., Mudgal, A. 2010. Agric. Biol. J. N. Am., 1: 40.

Prasad, M.N.V. 1998. Metal-biomelecule complexes in plants: Occurrence, functions, and applications. Analysis Magazine, 26(6): 25-28.

Qian, J.H., Zayed, A., Zhu, Y.L., Yu, M., Terry, N. 1999. Phytoaccumulation of trace elements by wetland plants: III. Uptake and accumulation of ten trace elements by twelve plant 
species. J. Environ. Qual., 28: 144855.

Sasaki, K., Ogino, T., Hori, O., Endo, Y., Kurosawa, K., Tsunekawa, M. 2003. Chemical transportation of heavy metals in the constructed wetland impacted by acid drainage. Materials Transactions, 44(2): 305-312.

Senila, M., Levei, E., Miclean, M., Senila, L., Stefanescn, L., Marginean, S., Ozunu, A., Roman, C. 2011. Influence of pollution level on heavy metals mobility in soil from NW Romania, Environ. Eng. Manag. J., 10: 59-64.
"Laboratory study on the survival of water hyacinth under several condition of heavy metal concentration". Adv. Environ. Res., 7: 321-334. [Abstract]

Standard Methods. 1995. The examination of water and wastewaters, American water public Health Assoc., American water works Assoc.19thed., NewYork.

Xia, Huilong, Ma, Xiangjuan. 2006. "phytoremediation of ethion by water hyacinth (Eichhornia crassipes) from water" Biores. Technol., 97: 1050-1054.

Soltan, M.E., Rashed, M.N. 2003.

\section{How to cite this article:}

Nashmeel Ali Hassan, Abdul-Rahman A. Al-Kubaisi and Abdul- Hameed M. Al- Obiadi. 2016. A Comparative Study between Three Aquatic Plants to Phytoremediation of Lead from Wastewater. Int.J.Curr.Microbiol.App.Sci. 5(6): 300-309. doi: http://dx.doi.org/10.20546/ijcmas.2016.506.034 